\title{
Analysis of the Quality of Nursing Services According to Hospital Accreditation 2012 Version, Reviewed from Baldrige Malcolm Criteria in Pasar Minggu Jakarta Selatan Hospital in 2017
}

\section{Rahmat Edi Wahyudi and Vetty Yulianty Permanasari²}

${ }^{1}$ Hospital Administration Postgraduate Programme, Faculty of Public Health, University of Indonesia

${ }^{2}$ Health Policy Administration Department, Faculty of Public Health, University of Indonesia

\section{Abstract}

The nursing services as an integral part of health services in hospitals are required to provide quality services according to standards. One of the standards used in

Corresponding Author: Vetty Yulianty Permanasari vetty.yulianty@ui.ac.id

Received: 17 October 2018 Accepted: 5 November 2018 Published: 5 December 2018

Publishing services provided by Knowledge $\mathrm{E}$

(c) Rahmat Edi Wahyudi and Vetty Yulianty Permanasari. This article is distributed under the terms of the Creative Commons Attribution License, which permits unrestricted use and redistribution provided that the original author and source are credited.

Selection and Peer-review under the responsibility of the 2 nd ICHA Conference Committee. the assessment of nursing services in Indonesia is Hospital Accreditation Version 2012 that assesses nursing service in eight standard chapters. There are several quality measurement models proven to be effective in quality management, one of which is the Malcolm Baldrige Criteria. This hospital is based on the Hospital Accreditation Version 2012, reviewed from Malcolm Baldrige Criteria as preparation for accreditation and continuous quality improvement. This research is descriptive analytic research with a qualitative approach through an in-depth interview of key informants, document review, observation, and focus group discussion. The results found that the implementation of nursing service standards according to the Hospital Accreditation Version 2012, especially the Patient and Family Chapter, the Patient and Family Education Chapter, and the Infection Prevention and Control Chapter have passed the minimum requirement of $80 \%$ achievement targets. Position Quality Score of Nursing Services Division at Pasar Minggu Hospital according to Hospital Accreditation Version 2012 reviewed from Malcolm Baldrige Criteria is on score 555.75, which is in 'Good Performance' predicate, indicating 'Average' quality level. The Nursing Services Division at Pasar Minggu Hospital can develop opportunities for improvement in senior leadership and strategy development criteria.

Keywords: Malcolm Baldrige, accreditation, hospital, nursing services

\section{G OPEN ACCESS}




\section{Introduction}

One of the health problems in Indonesia is the low quality of health services provided by health service providers. Hospitals as providers of health services are the leading organizations in providing health services to the community [1]. The community demands that hospitals can provide health services that meet the needs of patients, can be served easily, quickly, accurately, at affordable costs [2]. Nursing services as an integral part of health services in hospitals are also required to continuously improve the quality of services [3].

In an effort to improve the quality of hospital services, improve hospital patient safety, and improve protection for patients, the community and human resources of hospitals, a hospital is required to follow national accreditation [4]. One quality measurement model that has been widely known and proven to be effective in helping the successful implementation of quality management systems is the Malcolm Baldrige Criteria. Malcolm Baldrige's criteria focus on quality excellence for the entire organization within a comprehensive managerial framework, identifying and tracing all organizational outcomes, namely customers, products/services, finance, human resources and organizational effectiveness [5]. Quality measurement based on Malcolm Baldrige Criteria can be carried out on various types of organizations both business, non-profit, education, and health, including the quality of nursing services in hospitals.

Pasar Minggu South Jakarta Regional General Hospital (RSUD) as a place of research is one of the Hospitals owned by the Provincial Government of DKI Jakarta type B Noneducation located in the center of South Jakarta City [6]. Currently, the management of Pasar Minggu Hospital is in preparation for the accreditation of national hospitals. With the implementation of hospital accreditation using the 2012 Hospital Accreditation version, it certainly requires Pasar Minggu Hospital to make improvements and adjustments to the standards that have been set, including in the area of nursing services.

The purpose of the study was to analyze the quality of nursing services according to Hospital Accreditation Version 2012 in terms of 7 (seven) Malcolm Baldrige Criteria in Pasar Minggu Hospital in South Jakarta in 2017, so as to provide recommendations for improvement to Pasar Minggu South Jakarta Hospital in preparation for Hospital Accreditation, and improving the quality of nursing services in a sustainable manner. 


\section{Methods}

This study is a descriptive analytic study with a qualitative approach to analyze the quality of nursing services according to Hospital Accreditation Version 2012 in particular the Patient and Family Rights Chapter (HPK), the Patient and Family Education Chapter (PPK), Infection Prevention and Control Chapter (PPI) in terms of Malcolm Baldrige Criteria in Pasar Minggu South Jakarta Hospital in 2017. The study was conducted at Pasar Minggu Hospital, South Jakarta. Data collection was conducted in March-May 2017.

Primary data collection was carried out by conducting in-depth interviews of informants, conducting observation in the field, and Focus Group Discussion (FGD). While secondary data was obtained through review of related documents in the Field of Nursing Services, Medical Record Section, Marketing and Information Implementing Unit, Quality and Risk Management Team, and PPI Pasar Minggu Hospital Team. Indepth interviews were carried out on 8 informants, namely the Head of Nursing Services, Coordinators of the Nursing Implementing Unit, Quality and Risk Management Secretary, Team Secretary of the HPK Working Group, PPK Working Group Secretary, and PPI Working Group Team Secretary. FGD was conducted with the Head of Nursing Services, Coordinators of the Nursing Implementing Unit, and the Chair of the Nursing Committee. The research instrument used was in-depth interview guidelines that integrated Malcolm Baldrige Criteria with Hospital Accreditation Standards Version 2012 Chapter of PFR, PPK, and PPI, as well as secondary data completeness instruments. The data analysis process is carried out through content analysis with data reduction, data presentation, inference, and data verification steps, ending with final conclusions. Data validity uses triangulation method through source triangulation, data triangulation, and method triangulation.

After all the data collected will be grouped data according to the assessment of Malcolm Baldrige Criteria and Hospital Accreditation Standards in the HPK Chapter, KDP Chapter, and PPI Chapter. Data related to the Malcolm Baldrige Criteria are assessed by using scoring instructions on the dimensions of the Approach-Deployment-LearningIntegration (ADLI) process for criteria 1-6 and the dimensions of the results of LevelTrend-Comparison-Integration (Le-TCI) for criteria 7. The total scoring will be matched with a description of the Malcolm Baldrige Criteria Score Assessment. While the data related to Hospital Accreditation Standards Chapter of HPK, PPK, and PPI are assessed using an assessment scoring system adapted from the Hospital Accreditation Version 2012. 


\section{Results}

Based on the research methods described earlier, the following are the results and discussion of the research:

\subsection{Profile of nursing services in Pasar Minggu Hospital, South Jakarta}

Pasar Minggu South Jakarta Hospital is a hospital owned by the Provincial Government of DKI Jakarta type B Non-Education, officially operating since December 12, 2015. Located on J. TB Simatupang No. 1 South Jakarta, with a bed capacity of 468 beds. The Nursing Services Division is led by a Head of Division, oversees the Coordinator of the Implementation Unit, the Head of the Room, the Team Leader, PJ Shift, and the Implementing Nurse. Has a job description and work program, but does not have a Strategic Nursing Plan. Products include outpatient services, emergency services, hospitalizations, intensive care, delivery rooms, operating rooms, perinatology, and hemodialysis. The number of human resources as of April 2017 was 399 nurses. The HR manpower pattern has been established.

\subsection{Nursing services Sunday market hospital according to RS Accreditation 2012 version}

Based on the results of in-depth interviews, observation, document review and FGD implementation of nursing services according to Hospital Accreditation 2012 Version of the HPK Chapter, KDP Chapter, and PPI Chapter in Pasar Minggu Hospital, the document review matrix was prepared, and the scoring recapitulation matrix was adapted from the version RS Accreditation assessment 2012 to facilitate the assessment of the position of nursing services Pasar Minggu Hospital. From the matrix, it was found that the average achievement of PFR was $87 \%$, the average achievement of KDP was $87.5 \%$ and the achievement of the average PPI was $83.6 \%$. The three results illustrate that the implementation of nursing services at Pasar Minggu Hospital has exceeded the graduation target desired by the Accreditation Working Group Team of Pasar Minggu Hospital, which is a minimum requirement of $80 \%$ achievement for each chapter of the Hospital Accreditation Standards 2012 Version. 


\subsection{Nursing service quality Sunday market hospital according to RS Accreditation 2012 version judging from Malcolm Baldrige Criteria}

\subsubsection{Leadership}

From the results of the research on the leadership criteria in the Field of Nursing Services and an assessment of the process dimensions, the leadership criteria obtained a score of 64 from the total score of this criterion which is 120 points.

In this scoring, it can be seen that the role of Pasar Minggu Hospital head in building, directing and also striving to achieve the quality of nursing services according to the 2012 Hospital Accreditation version can be an integral part and support quality health services in hospitals. The Head of Nursing Services Division has a systematic, effective, and responsive approach to the basic needs of nursing services. The field of Nursing Services already has a clear vision, mission, and goals in managing hospital nursing services, which are derivatives of the vision, mission, and goals of Pasar Minggu Hospital. The dissemination of the vision, mission, and objectives of the Nursing Services Division have been carried out equally by senior leadership either through meetings or coordination meetings and has been documented in written form. The type of senior leadership obtained is participatory, willing to accept input and provide solutions to problems.

Management of Nursing Services in accountability and management steps toward the implementation of HPK, PPK, PPI including the performance evaluation of the RS leaders has been carried out well and there are almost no obstacles to implementation.

Dissemination of protection against HPK, health promotion through PPK, and PPI activities in nursing services have involved and varied in other units in hospitals.

Leadership can influence the behavior and quality and achievements of an organization. Weirich \& Koontz (1993) stated that leadership is an art or process to influence others so that they themselves are willing to their own abilities and enthusiastically work to achieve organizational goals [7].

\subsubsection{Strategic planning}

The results of the research scoring on the criteria of strategic planning in the Field of Nursing Services and an assessment of the process dimensions were carried out so that the strategic planning criteria scored 46.25 of this total score of 85 points. 
The strategy of implementing nursing services according to the 2012 Hospital Accreditation version, especially HPK, PPK, and PPI is translated into the Nursing Service Field Work Program that is systematic, effective, and responsive to service needs. The dissemination of the development of the Nursing Services Field Work Program is conducted through internal meetings, communication directly two-way, more related to improving services and resolving conflicts/patient complaints. Evaluation of the Nursing Service Field Work Program, especially in accordance with the 2012 RS Hospital Accreditation Standards, has not been carried out optimally, and not everything has been done in writing. Indicators to measure success already exist, especially those included in the KPI Director for nursing services, namely patient satisfaction, BOR, and emergency response time.

Duncan (1996) defines a strategic plan as a process used to examine the situation and develop procedures for decision-making within an organization [8]. The advantage of making strategic planning is to provide guidelines for the organization. By using strategic planning, the leader can clearly determine the goals and methods that will be used to achieve them, besides that planning will help leaders in anticipating problems that arise before the problem arises and also helps leaders to recognize risks and opportunities.

\subsubsection{Focus on customers}

From the results of the study on the criteria of focus on customers/patients in the Nursing Services Field, and an assessment of the process dimensions, the criteria for focusing on customers (patients) scored 53 from the total score of this criterion which is 85 points.

Approach through analysis of patient satisfaction surveys (effective), delivery of service complaints (responsive), and giving patients/families the opportunity to be involved in maintaining the quality of nursing services in accordance with the standards of (systematic) accreditation. Integrated dissemination with other units in the satisfaction survey by the hospital management, submission of complaints through suggestion boxes, through Qlue applications, social media, and electronic media, as well as the role of nurses who support patient involvement in nursing services according to accreditation standards. Evaluation based on facts, systematic, some improvements as organizational learning, including innovation to improve the efficiency and effectiveness of nursing services. This approach is integrated with other units and is in 
accordance with the needs of improving service quality of Pasar Minggu Hospital as a whole.

In addition to measuring patient satisfaction, the most important thing for how to meet patient needs and maintain the quality of hospital services is patient loyalty to the hospital or to the health service unit in the hospital. Patient loyalty is a response to the patient's commitment to consistently use health services [9].

\subsubsection{Measurement, analysis and knowledge management}

The results of the study on the criteria of measurement, analysis and knowledge management obtained a score of 60.75 of the total score on this criterion which is 90 points.

The Hospital Information System that has been integrated for all hospital services including the Nursing Services Division, although for the measurement of some parts in the hospital management is still not responsive. For hospital accreditation purposes there are still data on hospitals that have not been integrated with SIRS, such as the monthly PPI program data reporting from the head of the room. Evaluation and learning through SIRS data is carried out per service unit because when the research was carried out there was no special unit as a program data processor and information processor. This approach is integrated with all RS service units and is quite in accordance with the current accreditation needs and future development of hospitals.

Hospital services rely on information intensively, where information plays a vital role in decision-making [10]. The information system can be used as a strategic tool in providing services oriented to customer satisfaction. Another opinion was also expressed by Rowland \& Rowland (1984), namely the role of management information systems in hospitals can have medical functions and business functions [10].

\subsubsection{Focus on labor}

Scoring results on the criteria focus on the workforce in the Nursing Services Field and an assessment of the process dimensions is carried out, so the criteria for focusing on the workforce get a score of 64.25 of the total Malcolm Baldrige Criteria score of 85 points.

The approach used to complete the process by planning the fulfillment of nurses, nurses recruitment according to competence and work experience is prioritized, the process of mentoring new nurses even though they are not in ideal conditions because 
of the urgent needs of nurses and not comparable to the workload of nursing care at Pasar Minggu Hospital which is quite high. The capacity building of nurses is carried out through nursing training or seminars facilitated by the hospital, either as a form of reward for work performance or as a need for hospitals to fulfill accreditation requirements. Career development of nursing staff is regulated in accordance with statutory provisions and applicable standards. Evaluation is carried out to create a safe and comfortable work environment by fulfilling the rights of nurses, providing work facilities and facilities that support work, providing rewards in the form of training and certificates of appreciation, and imposing punishment according to the level of discipline violated.

In facing the challenges of the future, inevitably the hospital management must prepare itself well, especially in terms of human resources (13). One factor that supports the performance of an organization is to place the right person in the right job [11].

\subsubsection{Focus on operations}

From the results of the focus on operational, obtained a score on the assessment of the process dimension that is 68 of the total score Malcolm Baldrige Criteria 85 points. It can be seen that the score focused on the operations in the Nursing Service Division of Pasar Minggu Hospital is good.

The work system or process that runs in the Field of Nursing Services is carried out referring to the organizational structure in the Nursing Services Division, as well as the division of tasks and functions of each nurse according to placement rotation. Guidance/SPO for the implementation of nursing tasks, especially related to HPK, PPK, and PPI, is prepared by the Coordinator of the Nursing Quality Management Unit and/or the RS Work Team and/or the Accreditation Working Group Team. Operational effectiveness in nursing services is carried out by working according to the specified job description, work experience, and referring to the existing Guidelines/SPO. In the problem-solving process at work, nursing services look for the root causes of problems in work and solve them and communicate directly or through meetings. Information dissemination Guidance/SPO Nursing, especially those related to HPK, PPK, and PPI has been running, with direct communication and some through written forms. Dissemination is carried out in the implementation of nursing tasks, namely through teamwork that helps one another to provide optimal quality services to patients. Evaluation is carried out through direct communication through internal coordination meetings and 
through an assessment of the achievement of accreditation standards in nursing services.

Standard Operating Procedure (SPO) is a detailed and written instruction set (work order) that must be followed in order to achieve uniformity in carrying out a particular job by referring to the objectives to be achieved [12]. SOP is very important as an effort to realize the process of activities in the organization to be more effective, efficient and economical, the implementation of the work process can run with certainty because it can avoid various forms of irregularities and errors or if deviations occur and errors can be found and traced to the causes.

\section{Discussion}

From the results of the scores in all outcome criteria in the Nursing Services Field, in terms of assessment of products and processes, focus on customers/patients, focus on labor, leadership, and governance, as well as financial and market results, get a score of 199.5 from the total Criteria points. Malcolm Baldrige is 450 .

First, the product yield criteria and nursing service process obtained a score of 54 from the total perfection score of 120 . From the results of this product and process it was found that there was an increase in patient visits or growth in the number of patients in nursing services (ED, Outpatient, Inpatient), supported by RS service performance index data (BOR, AvLOS, BTO, TOI) which tends to increase and have been reported. The results of the description of the implementation of nursing services according to RS Accreditation 2012 version of the Chapter of HPK, PPK, and PPI shows that it has exceeded the criteria for achieving $80 \%$ of the minimum standard of graduation target. The favorable trend is the increasing number of patient visits and the increasing number of critical care service facilities in Pasar Minggu Hospital.

Second, the results of the focus on customer/patient criteria obtained a score of 38.25 of the total score of 85 . The results of services provided by nursing services when viewed from the patient satisfaction survey (February-March 2017) on outpatient and inpatient services ranged from the index satisfaction 4 ( $\geq 80-100 \%)$. This shows the patient's high satisfaction with the services of Pasar Minggu Hospital, including nursing services as an integral part of hospital health services. Efforts to improve patient satisfaction were carried out through suggestion boxes and RS patient satisfaction questionnaire surveys. This Satisfaction Survey consisted of an IGD questionnaire survey, Outpatient Questionnaire, Inpatient Questionnaire. All nursing survey results show a favorable trend. 
Third, the results of the focus on the workforce criteria obtained a score of 55.25 out of a total score of 85 . The results of the focus on the workforce were the availability of a routine budget from the Nursing Services Division to send nurses to take training and competency certification. Moreover, prior to hospital accreditation, Pasar Minggu Hospital sent many nurses to take part in training or in-house training to adjust to the 2012 RS Accreditation Standards assessment criteria. The work environment in nursing services according to the informants was quite comfortable and influenced the mood in work. A favorable trend is the increasing number of nurses in Pasar Minggu Hospital who attend training, both as a reward and to fulfill the accreditation requirements.

Fourth, the criteria of leadership and governance results obtained a score of 36 out of a total score of 80 . The results of the way the leadership of the Nursing Services Division regulates and manages the Nursing Services Division uses a participatory leadership approach, communication in a kinship either direct communication or task memo, so the leader expects and directs so that every nurse involved in the Field of Nursing Services understands their respective roles and responsibilities.

Fifth, the criteria for financial and market results obtained a score of 16 out of a total score of 8o. On the financial and market results in the Field of Nursing Services, it was found that basically, Pasar Minggu Hospital provided sufficient financial support for the implementation of quality nursing services especially according to Hospital Accreditation Version 2012 Chapter of HPK, Chapter PPK, and Chapter PPI. Financial and market trends are not reported.

There are 4 things that need to be considered in the approach to achieving excellent service through improving service quality, namely (1) Customers and expectations, (2) Improving performance, (3) Process Improvement, and (4) Culture that supports continuous improvement [9].

\section{Conclusion}

Implementation of Nursing Services According to Hospital Accreditation Version 2012 in Pasar Minggu Hospital

The average achievement in accordance with the standards of HPK, PPK, and PPI in nursing services at Pasar Minggu Hospital is $87 \%, 87.5 \%$ and $83.6 \%$, respectively. These three results show that nursing care at Pasar Minggu Hospital has passed the minimum passing standard targeted by the Accreditation Working Group Team, which is $80 \%$. To support the implementation of the KDP program, an RS Health Promotion Team (PKRS) was formed. The PPI Pasar Minggu Hospital currently only has 1 IPCN 
person, so it requires an additional IPCN officer according to the ideal ratio (1 officer: 100 beds). SIRS has not integrated PPI monthly data reporting from the head of the room.

Quality of Nursing Services According to Hospital Accreditation 2012 version Judging from Malcolm Baldrige's Criteria in Pasar Minggu Hospital

Opportunities for improvement (OFI) in the field of nursing services are in the criteria of senior leadership, and criteria for strategy development, aimed at improving the quality of continuing nursing. Almost all results of the evaluation of results dimensions (Le-T-C-I) indicate the initial stage of information or no comparison (comparison) is reported. The highest score in the process dimension is on the operational focus criteria, the lowest score on the strategic planning criteria. The score position of the total quality of the Nursing Service Field is 555.75, with the predicate 'Good Performance', with the level of performance 'Average' which indicates that the Nursing Service Division of Pasar Minggu Hospital is heading toward the stage of development and improvement.

Comparison of Malcolm Baldrige Criteria Assessment with 2012 version of Hospital Accreditation in Nursing Services Pasar Minggu Hospital

Based on the dimensions, indicators, and measurement aspects, it was found that in terms of the dimensions of the Malcolm Baldrige Criteria and Hospital Accreditation in 2012 version it can be said to be in line, mutually reinforcing, and both have input, process and output/outcome components. From the aspect of assessment indicators, the Malcolm Baldrige Criteria can be adapted and developed and can be broken down depending on the organization being assessed. Whereas Hospital Version 2012 Accreditation excels in the details of the process (policies, documents, operations) of the items being assessed, and is more lockable. Furthermore, from the aspect of measuring instruments, the 2012 Malcolm Baldrige Criteria and Hospital Accreditation criteria are equally able to examine strengths and identify opportunities for improvement (OFI). However, Malcolm Baldrige's criteria are superior in comparing (comparing) the results of organizational performance with other organizations in a clear and measurable manner.

\section{References}

[1] Republic of Indonesia. (2009). Law of the Republic of Indonesia Number 44 of 2009 concerning Hospitals. Indonesia.

[2] Ilyas. (2004). The Face of Our Health Services. Jakarta: Djambat. 
[3] Republic of Indonesia. (2014). Republic of Indonesia Law No. 38 of 2014 concerning Nursing. Indonesia.

[4] Ministry of Health of the Republic of Indonesia. (2012). Regulation of the Minister of Health of the Republic of Indonesia Number 12 of 2012 concerning Hospital Accreditation. Indonesia.

[5] Sadikin, I. (2010). Bunga Rampai Criteria for Malcolm Baldrige National Quality Award (MBNQA). Jakarta: Lembayung Center Indonesia.

[6] Pasar Minggu South Jakarta Hospital. (2016). Profile of the South Jakarta Sunday Market Regional General Hospital. Jakarta.

[7] Febriyanty, D. (2015). Analysis of the quality of hemodialysis unit services in terms of Baldrige Criteria at Anna Medika Hospital. University of Indonesia.

[8] Ayuningtyas, D. (2014). Strategic Planning for Health Service Organizations. Jakarta: Book Division of PT Raja Grafindo Persada College.

[9] Satrianegara, M. F. Organization and Management of Health Services, Theories and Applications in Puskesmas and Hospital Services. Jakarta: Salemba Medika.

[10] Aditama, T. Y. (2004). Home Administration Management. Jakarta: University of Indonesia Press.

[11] B. (2004). Useful, Quality Assurance Hospital Services. Yogyakarta: TB. Amanah.

[12] The International Council for Harmonization of Technical Requirements for Pharmaceuticals for Human Use (ICH). (2016). Integrated Addendum To ICH E6 (R1): E6 (R2) Guidelines for Good Clinical Practice. ICH Harmonized Guideline. Retrieved from https://www.ich.org/fileadmin/Public_Web_Site/ICHProducts/ Guidelines/Efficacy/E6/E6_R2_Step_4_2016_1109.pdf

[13] Baldrige Performance Excellence Program. (2017). 2017-2018 Baldrige Excellence Framework: A Systems Approach to Improving Your Organization's Performance (Health Care). Retrieved from https://www.nist.gov/baldrige (accessed on February 20, 2017). 